\begin{tabular}{|c|c|c|}
\hline Beitr. Ent. & Keltern & ISSN 0005-805X \\
\hline $\mathbf{5 9}(2009) 2$ & S. $325-328$ & 15.12 .2009 \\
\hline
\end{tabular}

\title{
On the identity of Amegilla sesquicincta (ERICHSON) and the type species of Dizonamegilla
}

\section{(Hymenoptera: Apidae)}

\author{
Michael S. Engel
}

\begin{abstract}
Summary
Notes are provided on the identity and nomenclature of Amegilla sesquicincta (Erichson), a name long confused in its application. Amegilla sesquicincta is a Senegalese species of uncertain identity while the species from India to which this name has been applied is preoccupied and accordingly named A. dizona nom. $\mathbf{n}$. As this name was used as the type species of the subgenus Dizonamegilla, the question of the type species for this group is addressed and subsequently fixed as A. dizona in accordance with ICZN regulations.
\end{abstract}

Key words

Nomenclature, Amegilla, Senegal, India, Apidae, Anthophila.

\section{Zusammenfassung}

Vorliegende Arbeit behandelt die Identität und Nomenklatur von Amegilla sesquicincta (ERICHson). Die Verwendung dieses Namens war lange Zeit unklar. Amegilla sesquicincta ist eine senegalesische Art von unsicherer Identität. Der auf die indische Art angewendete Name ist jedoch präokkupiert. Deshalb wird sie hiermit A. dizona nom. n. genannt. Amegilla sesquicincta war auch als Typusart der Untergattung Dizonamegilla festgelegt. Aufgrund der Fehlbestimmung dieser Art muss auch die Frage der Typusart neu behandelt werden. Entsprechend den Regeln der ICZN wird A. dizona als Typusart festgelegt.

Brooks (1988), seemingly following a long-standing confusion started by Dalla Torre (1896), equated Amegilla sesquicincta (ERICHSON in KLUG, 1842) (accidentally accorded to "ERICHSON and Klug") with A. bicincta (Fabricius, 1793, nec Schrank, 1781) from India. Amegilla sesquicincta, however, was a Senegalese species, not an Indian one. As mentioned, it appears as though Dalla Torre (1896) was the first to make this misattribution, one that hitherto been followed by all subsequent authors (e.g., Cockerell, 1907). Interestingly, Bingham (1897) correctly interpreted $A$. bicincta. Unfortunately, the actual name of the species is a junior primary homonym and is, therefore, replaced herein. From the locality and ERICHSON's description it is evident that his species was likely Amegilla nubica (Lepeletier de SAint Fargeau, 1841).

Erichson described Megilla sesquicincta from a series of both sexes from Senegal. From the circumstances in which the species was described, in a price-list of Museum duplicates, it is 
virtually certain that ERICHSON's original type series became dispersed. For the Berlin Museum price-lists of duplicates see Horn \& KaHLE (1937: 398). It was through these and similar price-lists issued by other museums, especially in the first half of the nineteenth century, that what were - though not at that time recognized as such - the type series of many species became depleted, while the specimens dispersed to other public and to private collections lost their identity as syntypes.

Brooks (1988: 505, 557) under the name "Megilla sesquicincta W. Erichson \& J. Klug", designated as neotype a $0^{\star}$ with data "South India, Pondicherry State, Karikal, April 1964 (P. S. Nathan)" in the Division of Entomology, University of Kansas Natural History Museum (Lawrence, Kansas, USA). This author gave the type locality as "India, Pondicherry State, Karikal", and stated "The supposed type material of M. sesquicincta in Berlin, consisting of four specimens, is not from the type locality nor of the proper sex [but ERICHSON described both sexes so this statement is enigmatic]. There is no doubt of its identity from ERICHSON's description and from where it occurs in India”. It can only be assumed that Brooks either failed to read or ignored both KLUG's introduction to the Doubletten-Verzeichniss and the heading of that section of it (DoublettenVerzeichniss von Senegallensischen [present italics] Insecten, \&c.) in which ERICHsON's description of sesquicincta was printed; or, if he did notice the latter, supposed Senegal to be somewhere in India.

The soi-disant neotype, from peninsular India, has nothing whatever to do with ERICHson's species from Senegal. The common Indian species to which the Karikal specimen belongs is $A$. dizona ENGEL, nom. n. [= Apis bicincta FABricius, 1793, a junior primary homonym of Apis bicincta SCHRANK, 1781]. ERICHSON's Senegal insect was evidently a species of the group of $A$. nubica, and likely referable to that species or a putatively undescribed species that ranges across the southern boundaries of the Sahara to Darfur Province in the Sudan.

Lastly, Brooks (1988) gave as a further synonym of his "sesquicincta" Anthophora indica Radoszkowsky, 1882. Radoszkowsky's species is, however, a synonym of Amegilla violacea (Lepeletier de Saint Fargeau, 1841) ( $c f$. Hedicke, 1942: 215), and has nothing to do with those bees resembling or allied to $A$. sesquicincta, $A$. nubica, and others.

The taxonomic details for $A$. sesquicincta and the Indian species (“bicincta”) are provided here.

\section{Amegilla dizona ENGEL, nom. $n$.}

Apis bicincta Fabricius, 1793: 338 [0]]; "in India orientali Mus. Dom. Lund”. Nomen praeoccupatum (nec Apis bicincta Schrank, 1781). Zimsen [1964: 418, no. 1124, "Copenhagen 2 specimens. (Kiel 3 specimens)"]. A lectotype should be selected from the Copenhagen specimens.

Centris bicincta (Fabricius); Fabricius, 1804: 358.

Megilla bicincta (Fabricius); Illiger, 1806: 142.

Anthophora bicincta (Fabricius); Lepeletier de Saint Fargeau \& Audinet-Serville, 1828: 798.

"Megilla sesquicincta (Erichson)"; Dalla Torre, 1896: 259 [misidentification].

Podalirius bicinctus (Fabricius); Dalla Torre, 1896: 259.

“Amegilla sesquicincta (ERICHson \& KLUG)"; Brooks, 1988: 573 [misidentification, invalid neotype designation (the "neotype" in the Division of Entomology, University of Kansas Natural History Museum must be set aside in favor of one of FABRICIUs's original specimens)]. 


\section{Amegilla sesquicinta (ERICHSON), nom. dub.}

Megilla sesquicincta ERICHSON In KLUG, 1842: [Doubletten-Verzeichniss von Senegallensischen Insecten mit Diagnosen neuer Arten von Klug und Erichson] 14 [ $\left.90^{*}\right]$; "Senegall". No syntypes traced in Berlin; two $\sigma^{\star} \sigma^{*}$ in that collection, determined by Hedicke (1942) as "Amegilla sesquicincta ERICHSON", are actually Indian "bicincta" [= dizona, herein].

Amegilla (Dizonamegilla) sesquicincta (ERICHson); Brooks, 1988: 505 [misidentification (= dizona ENGEL, herein); authorship erroneously given to "ERICHSON \& KLUG"; invalid neotype designation].

As Brooks (1988) designated his "Megilla sesquicincta" as the type species for the new subgenus Dizonamegilla, this calls into question the identity and application of the genus-group name. As the type species designation was based on a misidentification, a new type species must be designated that is either the nominal species originally cited or the taxonomic species actually involved (ICZN, 1999: Art. 70.3). Given that the nominal species, sesquicincta, is a nomen dubium, I here designate the taxonomic species involved as it best promotes nomenclatural stability. Thus, the type species of Dizonamegilla is now fixed (under Article 70.3.2) as Amegilla dizona Engel, nom. n. (= Apis bicincta Fabricius, 1793), misidentified as Megilla sesquicincta ERICHSON in KLUG, 1842 in the original designation by BROoks (1988: 505).

\section{References}

Bingham, C. T. 1897: The Fauna of British India, including Ceylon and Burma. - Pp. xxix + 579. London: Taylor and Francis.

Brooks, R. W. 1988: Systematics and phylogeny of the anthophorine bees (Hymenoptera: Anthophoridae; Anthophorini). - University of Kansas Science Bulletin 53 (9): 436-575.

Cockerell, T. D. A. 1907: On a collection of Australian and Asiatic bees. - Bulletin of the American Museum of Natural History 23 (10): 221-236.

Dalla Torre, C. G. DE [K. W., von] 1896: Catalogus Hymenopterorum, hucusque descriptorum systematicus et synonymicus. Volumen X: Apidae (Anthophila). - Pp. 643. - Lipsiae [Leipzig]: Engelmann.

Fabricius, J. C. 1793: Entomologia Systematica emendata et aucta: Secundum classes, ordines, genera, species adjectis synonymis, locis, observationibus, descriptionibus [vol. 2]. - Pp. viii + 519. - Hafniae [Copenhagen]: Proft.

Fabricius, J. C. 1804: Systema Piezatorum secundum ordines, genera, species, adiectis synonymis, locis, observationibus, descriptionibus. - Pp. $439+30$ - - Brunsvigae [Brunswick]: Reichard.

Hedicke, H. 1942: Zur Nomenklatur der Pelzbienen (Hym. Apid.) (5. Beitrag zur Kenntnis der Gattung Anthophora Latr.). - Deutsche Entomologische Zeitschrift 1942: 214-216.

Horn, W. \& Kahle, I. 1937: Über entomologische Sammlungen, Entomologen \& Entomo-Museologie (Ein Beitrag zur Geschichte der Entomologie). Teil III. - Entomologische Beihefte aus Berlin-Dahlem 4: i-vi, 297-536.

iCZN [International Commission on Zoological Nomenclature]. 1999: International Code of Zoological Nomenclature [Fourth Edition]. - Pp. xxix + 306. - London: International Trust for Zoological Nomenclature.

IlLiger, K. 1806: William Kirby's Familien der bienenartigen Insekten, mit Zusätzen, Nachweisungen und Bemerkungen. - Magazin für Insektenkunde 5: 28-175.

KLUG, J. C. F. 1842: Doubletten-Verzeichniss von senegallensischen Insecten mit Diagnosen neuer Arten von Klug und Erichson. - Pp. 15. - Berlin: Zoologischen Museums der Königlichen Universität zu Berlin.

Lepeletier de Saint Fargeau, A. L. M. 1841: Histoire Naturelle des Insectes-Hyménoptères [vol. 2]. - Pp. 680. - Paris: Roret. 
Lepeletier de Saint Fargeau, A. L. M. \& Audinet-Serville, J. G. 1828: [Sections]. - In: Latreille, P.A. (editor), Encyclopédie Méthodique. Histoire Naturelle. Entomologie, ou Histoire Naturelle des Crustaces, des Arachnides et des Insectes. Tome Dixième [Part 2]. - Pp. 345-832. - Paris: Agasse.

RadoszKowsky, O. 1882: Opisanie nowych gatunków Błonkoskrzydłych (Hymenoptera). - Wiadomości z Nauk przyrodzonych 2: 72-81.

Schrank, F. von Paula 1781: Enumeratio insectorum Austriae indigenorum. - Pp. xxiv + $548+$ [4], + 4 pls. - Augustae Vindelicorum [Augsburg]: Klett and Franck.

Zimsen, E. 1964: The Type Material of I. C. FAbricius. - Pp. 656. - Copenhagen: Munksgaard.

\section{Author's address:}

Prof. Dr. Michael S. Engel

Division of Entomology (Paleoentomology)

Natural History Museum

1501 Crestline Drive - Suite 140

University of Kansas

Lawrence, Kansas 66049-2811

United States

\section{Subject editor:}

Prof. Dr. H. H. Dathe 